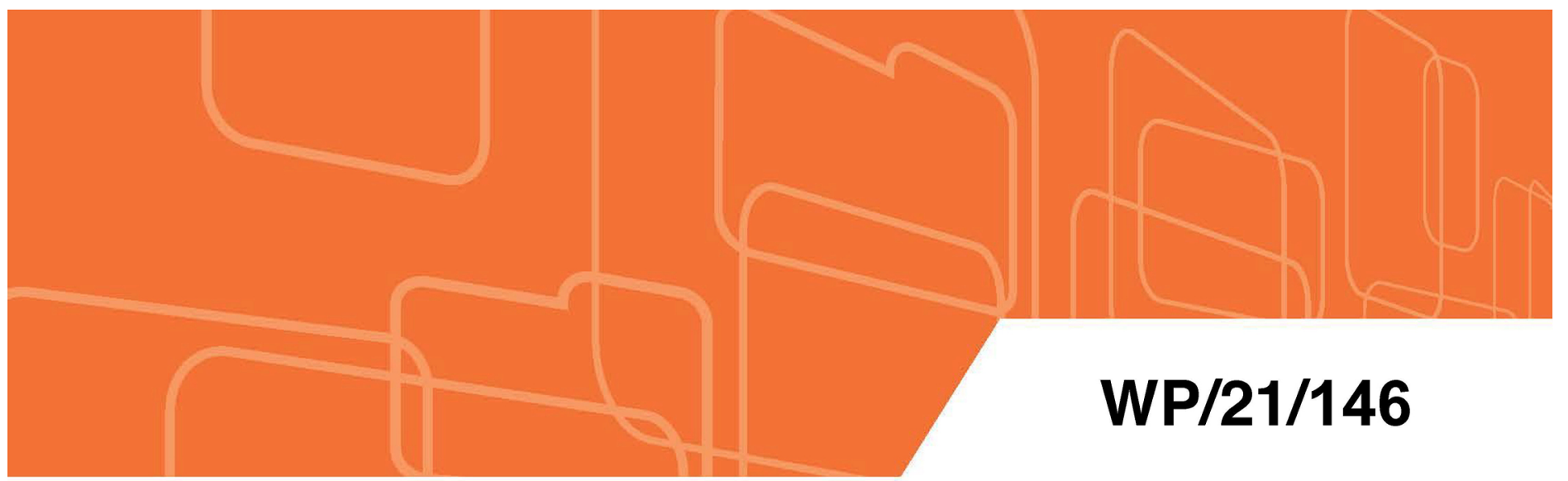

IMF Working Paper

\title{
IMF Programs and Financial Flows to Offshore Centers
}

\author{
by Shekhar Aiyar and Manasa Patnam
}

IMF Working Papers describe research in progress by the author(s) and are published to elicit comments and to encourage debate. The views expressed in IMF Working Papers are those of the author(s) and do not necessarily represent the views of the IMF, its Executive Board, or IMF management. 


\title{
IMF Working Paper
}

European Department

\section{IMF Programs and Financial Flows to Offshore Centers ${ }^{1}$ \\ Prepared by Shekhar Aiyar and Manasa Patnam}

Authorized for distribution by Shekhar Aiyar

May 2021

\section{IMF Working Papers describe research in progress by the author(s) and are published to elicit comments and to encourage debate. The views expressed in IMF Working Papers are those of the author(s) and do not necessarily represent the views of the IMF, its Executive Board, or IMF management.}

\begin{abstract}
This paper examines whether IMF lending is associated with increases in outflows to offshore financial centers (OFCs), known for bank secrecy and asset protection, relative to other international destinations. Using quarterly data from the BIS on bilateral bank deposits, we are unable to detect any positive and statistically significant effect of IMF loan disbursements on bank deposits in OFCs. The result holds even after restricting the sample to the duration of the IMF program, where disbursement quarters and non-disbursement quarters should be subject to similar degrees of macroeconomic stress. It is also robust to using the scheduled tranche of disbursements as an instrument for actual disbursements. While the effects vary by the type and conditionality of the IMF program, as well as the amount of lending, none of the effects are found to be positive and statistically significant. We also estimate whether the recent surge in emergency lending, during the Covid-19 crisis, is associated with an increase in outflows to OFCs but find no evidence to support this.
\end{abstract}

JEL Classification Numbers: D73, F35, P16.

Author's E-Mail Addresses: saiyar@,imf.org, mpatnam@,imf.org

\footnotetext{
${ }^{1}$ The authors would like to thank Sascha Buetzer, Enrica Detragiache, Gita Gopinath, Mizuho Kida, Erik Klok, Tobias Krahnke, Paolo Mauro, Huy Nguyen, Swapan-Kumar Pradhan, Simon Paetzold, Antonio Spilimbergo for useful comments. All remaining errors and omissions are our own. The views expressed in IMF Working Papers are those of the author(s) and do not necessarily represent the views of the IMF, its Executive Board, or IMF management.
} 


\section{INTRODUCTION}

A growing literature on aid effectiveness seeks to investigate the link between foreign aid and corruption. On the one hand, aid can help improve the quality of governance by requiring structural or institutional reforms to be implemented. On the other hand, aid can induce moral hazard and create perverse incentives for recipient countries not to mobilize savings or undertake serious governance reforms (Quibria, 2014; Svensson, 2000). The empirical evidence is inconclusive. Most empirical studies take a cross-country approach and analyze the pattern of corruption against the quantity of aid received. Some find a positive relationship between aid and rent-seeking behavior (Alesina and Weder, 2002). Some find that foreign aid reduces corruption (Okada and Samreth, 2012; Tavares, 2003) Other studies find no significant causal relationship (Menard and Weill, 2016).

While considerable effort has been devoted to finding structural relationships between aid and corruption, an understudied but central question is the extent to which foreign aid is diverted and "captured" by local elites. While it is possible that aid could structurally alter the nature of corruption in the recipient country, a material leakage from the flow of aid directly prevents it from being used for the intended purpose, and raises a very practical accountability concern. Moreover, it is plausible that different types of aid, or aid provided by different institutions, are subject to different degrees of diversion; if this is the case then we would expect corresponding heterogeneity in aid effectiveness. One reason for the sparse evidence on aid diversion is the difficulty of matching the timing of aid disbursements with corrupt activity, as high-frequency data tracking both indicators are not readily available. The fungibility of aid can also present challenges, in terms of being able to identify ex-post outcomes with the intended purpose of aid disbursements.

A recent paper, Andersen, Johannesen, and Rijkers (2020), proposes a novel way to measure the diversion of foreign aid provided by the World Bank. The authors use data from the Bank for International Settlements (BIS) to show that an increase in World Bank aid is associated with an increase in outflows from the recipient country to offshore financial centers (OFCs). Importantly, the outflows to OFCs increase by significantly more than outflows to other international destinations. Since OFCs are characterized by laws enshrining bank secrecy and asset protection, they argue that this differential outflow reflects corrupt activity and provides a good measure of aid diversion. Moreover, since it is well known that OFC bank accounts are overwhelmingly held by individuals at the very high end of the income distribution (Alstadsæter, Johannesen, and Zucman, 2019; LondoñoVélez and Ávila-Mahecha, 2018), the aid diversion is almost certain to be undertaken by elites in the recipient country. The paper estimates a substantial "leakage rate" of about 7.5 percent for World Bank aid. ${ }^{1}$

\footnotetext{
${ }^{1}$ In a different vein, Dykstra and others (2019) analyze health outcomes associated with aid to expand vaccination coverage in developing countries, estimating that the actual waste (vaccines not leading to vaccination) ranges between 0.5 percent and 15 percent of vaccines delivered. Their estimate of aid diversion derives from observing the excess of (vaccination) aid over and above the total vaccination rate in a given country year.
} 
In this paper, we ask whether the same holds true for lending by the International Monetary Fund (IMF). The question is of interest not just because of the magnitude and global reach of IMF assistance, but more importantly, because IMF lending is structurally different from World Bank lending in many ways. First, unlike development banks, the IMF does not provide financial assistance for specific projects; instead, IMF financing is aimed at helping member countries tackle balance of payments problems and stabilize their economies (IMF, 2020). Second, IMF lending is episodic rather than continuous. In general the IMF lends to countries facing macroeconomic crises, with the lending relationship expiring once the economy has recovered from the crisis. While there are cases where one IMF program has been rapidly succeeded by another, this is the exception rather than the rule. ${ }^{2}$ Third, IMF lending is generally less concessional than World Bank lending. In particular, member states that are not classified as low-income countries pay market interest rates on IMF loans (although at the time of the program they may be constrained from market borrowing at any price). Finally, IMF lending is associated with conditionality; recipient countries agree to a program of economic reforms including macroeconomic targets that are monitored at regular intervals through the duration of the program. Formally, under its Articles of Agreement, the IMF must establish "adequate safeguards" for the use of its resources, including limits on how much can be borrowed, conditions on the loans, measures to deal with misreporting or arrears, and safeguards assessments of central banks. ${ }^{3}$

Given these structural differences between IMF lending and World Bank lending, we would not expect to find identical or even similar results on aid diversion. And indeed we do not. Using a difference-in-difference specification that allows us to difference out common shocks to cross-border flows which can be jointly correlated with IMF lending, we find no positive and significant association between IMF lending and flows to OFCs. In fact, in our baseline specification we find a decrease in OFC flows (both in absolute terms and relative to outflows to non-OFCs) in quarters where a country receives a loan disbursement under an IMF program.

By design, the IMF lends to countries facing economic stress. Consequently there is an econometric challenge in separating the impact of the IMF disbursements on offshore flows from the impact of the underlying macroeconomic disturbance on these flows. Our baseline difference-in-difference strategy solves the identification problem on the assumption that the macroeconomic stress affects outflows to OFCs and non-OFCs alike, so that any differential impact can be attributed to the IMF disbursement. While this seems a plausible assumption, it may not always hold. Therefore we supplement our baseline regressions with several other strategies.

First, we restrict our sample to only those quarters in which countries had IMF programs. The total loan amount under an IMF program is disbursed in discrete "tranches", and not every program quarter is associated with a disbursement. Typically tranches are dis-

\footnotetext{
${ }^{2}$ The average duration between successive programs is eight quarters and there are only 10 percent of cases where a new program is followed in the same or subsequent quarter.

${ }^{3}$ For further details see the IMF's website on safeguards.
} 
bursed twice a year over a multi-year period, so about half the program quarters are not associated with a disbursement (see Appendix Figure A1 for an example). There is no compelling reason to suppose that economic stress in disbursement quarters is systematically different from economic stress in non-disbursement quarters. So applying our difference-in-difference methodology to the restricted sample of IMF program quarters should allow us to isolate the impact of IMF disbursements on offshore flows.

Second, we run a placebo specification by dropping all IMF program periods from the sample, and artificially constructing a "placebo disbursement" several quarters before the program began. If we were to observe a statistically significant coefficient on the placebo quarter, this would cast doubt on our identifying assumption that there is a common trend to OFC and non-OFC outflows in the absence of an IMF program.

Third, we use an instrumental variables specification that exploits the fact that the ex ante disbursement schedule of an IMF program, agreed at the time that the program is approved by the IMF's Executive Board, frequently differs from the actual disbursement schedule. The disbursement of each loan tranche is contingent on the country fulfilling certain conditions. Non-fulfillment of program conditionality can lead to a tranche disbursement being postponed or cancelled. Since the original schedule of disbursements should be orthogonal to shocks in future quarters that cause actual disbursements to deviate from the timetable, it is a plausible instrument for actual disbursements.

Our baseline results are robust to each of these strategies. We uniformly fail to detect any positive significant effect of IMF disbursements on flows to offshore bank accounts.

Concerns about the diversion of IMF assistance are particularly germane during the Covid-19 pandemic, which has led to severe recessions in advanced, emerging and lowincome economies alike. In response to the global crisis, the IMF has ramped-up lending disbursements to unprecedented levels, as shown by a quarterly time series of aggregate IMF disbursements from 1995 to 2020 (Figure 1). IMF disbursements reached a record high in the second quarter of 2020 as an urgent reaction to the high demand for assistance by member countries adversely impacted by the pandemic. Moreover, lending under emergency programs-which carry less strict conditionality than standard programs-reached an all-time high in the second quarter, while the share of emergency lending peaked in the third quarter. Yet, as noted frequently, corruption risks do not disappear in a crisis, and preventing the misuse of international assistance becomes, if anything, more important than ever because of the sums involved. ${ }^{4}$

\footnotetext{
${ }^{4}$ See, for example, blogs by Transparency International and the IMF on governance safeguards in IMF programs, especially in the context of the Covid-19 crisis.
} 
Figure 1. IMF disbursements (quarterly aggregates, USD billions)

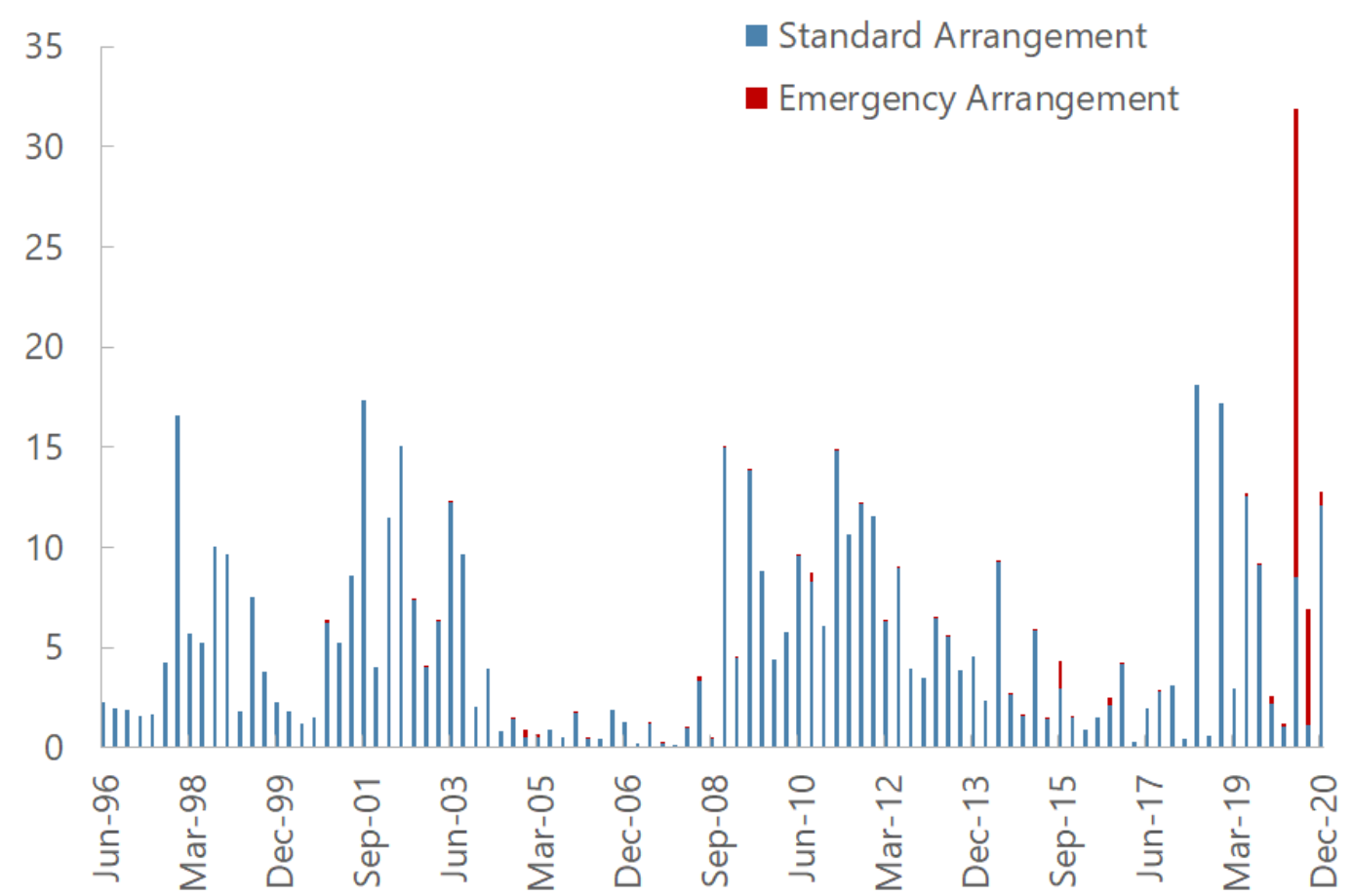

The figure shows quarterly IMF disbursements. Emergency Arrangement is RCF/RFI/Emergency-Assistance Facilities. Sources: IMF Finance Department.

To examine how IMF lending impacted financial flows during the period when IMF emergency lending peaked in response to the Covid-19 pandemic, we extend our sample to the second and third quarter of 2020. Since the lending surge in these quarters came in response to the global spread of Covid-19, the episode comprises a natural experiment, allowing us to examine aid diversion with respect to a plausibly exogenous event. The results confirm our main finding; there is no evidence of an associated increase in outflows to OFCs from IMF loan recipients.

In addition to the literature on aid effectiveness, our paper contributes to the burgeoning literature on the impact of IMF programs on economic outcomes. A number of empirical papers have examined the effect of IMF programs on economic growth and other social outcomes. The evidence is mixed, with the results appearing to vary considerably depending on the methodology employed for identification and the precise yardstick used to measure aid effectiveness (see for a review Dreher, 2006, 2009; IMF, 2019; Steinwand and Stone, 2008). Our paper sidesteps the broader question of whether economic outcomes are ultimately improved and focuses on the more specific issue of whether the aid is captured and diverted to offshore accounts. The answer to this question is arguably first-order, since the diversion of IMF program assistance would preclude the use of these funds for the intended purpose of economic stabilization. 
The rest of the paper is organized as follows: the next section (Section II) describes the data used in our analysis, while Section III discusses our empirical strategy. Section IV presents our main results and Section V provides further robustness checks. Section VI explores sample heterogeneity across several dimensions. Section VII concludes.

\section{DATA}

\section{A. Bank Deposit Flows}

We measure cross-border banking flows using quarterly data from the Bank of International Settlement's (BIS) locational banking statistics (LBS) database. ${ }^{5}$ The LBS provide information about the currency composition of banks' balance sheets and the geographical distribution of their counterparties. The data capture the outstanding financial assets and liabilities of internationally active banks located in reporting countries against counterparties residing in more than 200 countries $^{6}$. The data represents around 94 percent of all cross-border banking activity (BIS, 2020).

As in Andersen and others (2017), we exploit the sectoral breakdown provided by the LBS to focus on outflows from the non-bank sector. Among the 43 reporting countries contributing to the LBS in our sample, 15 are classified as OFCs and the remaining 28 as non-offshore financial centers (NOFCs). Definitions of what classifies as an offshore center vary. IMF (2000) proposes an operational definition that encompasses jurisdictions with relatively large numbers of financial institutions engaged primarily in business with non-residents or centers with some or all of the following characteristics: low or zero taxation; moderate or light financial regulation; banking secrecy and anonymity. Such institutional characteristics - such as bank secrecy rules that ensure strict confidentiality and legal arrangements that facilitate asset protection - can make them attractive places to divert and hide funds. A recent literature has therefore used this data as a source of information on hidden wealth, and more generally as a proxy for corruption (Andersen and others, 2017; Johannesen and Zucman, 2014; Zucman, 2013).

The sectoral and counterparty breakdowns provided in the LBS data allow us to disaggregate each country's total foreign deposits into those residing in OFCs and those in NOFCs. More specifically, we construct time series for the OFC and NOFC deposits of the nonbank sector of 217 countries, from the fourth quarter of 1995 to the fourth quarter of 2019. In annex tables A3 and A4 we also verify our results using the publicly disclosed version of the LBS dataset, which is not as comprehensive as the restricted data series. ${ }^{7}$

\footnotetext{
${ }^{5}$ Much of the LBS data is available publicly at the BIS data website. Our study includes, in addition, restricted data made available to researchers by the BIS, with more comprehensive coverage of bilateral claims.

${ }^{6}$ Banks record their positions on an unconsolidated basis, including intragroup positions between offices of the same banking group.

${ }^{7}$ In particular, the restricted data series contains bilateral breakdowns for a larger set of countries than the public database.
} 


\section{B. IMF Lending Arrangements}

The IMF lends to its member countries with the aim of resolving balance of payments problems. Formally, a country enters a 'program' with the IMF which involves a phased disbursement of the total loan amount over a specific time-period (usually several quarters). The timing of each disbursement is pre-arranged at the time that the country first enters an IMF program. However the actual receipt of funds is contingent on the country satisfying certain conditionalities, typically in the form of various macroeconomic policy commitments such as keeping the fiscal deficit or money supply below a certain ceiling, or keeping international reserves above a certain floor (IMF, 2018). Macroeconomic targets are sometimes complemented by commitments to undertake structural reforms, for example in the areas of tax policy or public procurement. In what follows, we will use the term 'tranche' to refer to a portion of the total loan amount that is released to a recipient country following a successful review of its performance against the required set of conditionalities.

To clarify concepts around the timing of IMF disbursements, Figure 2 shows an illustrative timeline of an IMF lending arrangement. We define the pre-program period as a certain number of quarters leading up to the program period (quarters labelled with blue vertical ticks). When an IMF lending arrangement is agreed, the total loan amount is split into tranches to be phased over several quarters (see Annex Figure A1 for an example of tranching under a recent IMF program). Each quarter in which a disbursement is scheduled is associated with a review of conditionality agreed under the program (quarters labelled with solid gray vertical ticks). However for several reasons, including breaches of conditionality, the schedule of disbursements may differ from what is actually disbursed. The figure shows an example where actual disbursements occur only in quarters $t$ (the program arrangement quarter), $t+2$, and $t+4$ (solid gray vertical ticks with red circles) and not in $t+6$ as per the original schedule. In our analysis, we count only quarters $t, t+2$ and $t+4$ as disbursement quarters and count only the time between $t$ and $t+4$ as the IMF program period. 
Figure 2. Timing of IMF program disbursements

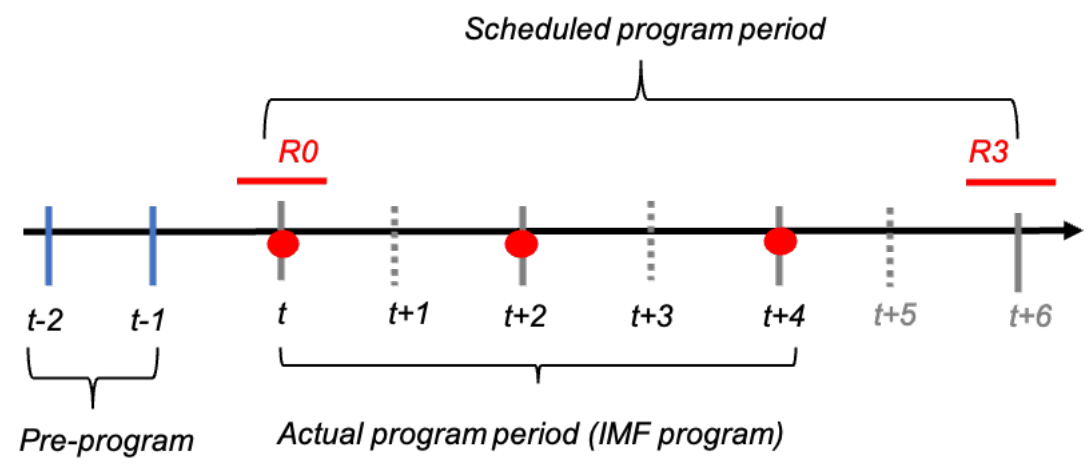

The figure presents an illustrative timeline of an IMF lending arrangement. The blue vertical ticks correspond to the quarters before a program is put in place (pre-program period). The solid gray vertical ticks reference the quarters in which loan amounts are scheduled to be disbursed at the time the program is arranged at time $t$ (i.e., at the initial program review R0). The solid gray vertical ticks with red circles reference the quarters in which loan amounts are actually disbursed under the program which is arranged at time $t$. Dashed gray vertical ticks reference quarters, within the program period, but when no disbursements are made.

Data on programs and disbursements is taken from the IMF Financial Database, which provides cross-country historical financial data since 1984, including on each member state's quota (a measure of how much the country is eligible to borrow, which is linked to its capital share in the IMF), SDR holdings, outstanding credit, and projected payments due to the IMF. We supplement this with information from the Monitoring of Fund Arrangements (MONA) database ${ }^{8}$. This database contains information on each country's lending program with the IMF at any given point in time and the characteristics of that program. In particular, it tracks both the timing and amount of IMF disbursements against the initially agreed schedule, and also keeps a record of performance against program targets. Data are collected at the time of the program's approval by the IMF Executive Board, and following each review.

Our two key variables from the data on IMF lending are: the quarter in which a country receives an IMF disbursement and the quarters in which it is under an IMF program. We also observe the original timetable for tranche disbursements, constructed at the time that the program was approved ${ }^{9}$. In addition, we collate information on the characteristics of the program that help us to later examine the role that program heterogeneity might play in aid diversion. In particular, we are interested in the degree of concessionality and conditionality of the programs. We differentiate between programs arranged under the so-called General Resources Account (GRA), which charge market-based interest rates, and those falling under the Poverty and Growth Reduction Trust (PRGT), which offer highly concessional terms. We also differentiate between programs with little to no conditionality (Emergency Relief Programs) and those with standard conditionality (Standard Programs).

\footnotetext{
${ }^{8}$ Dissemination of MONA data are made to imf.org within a few weeks following Executive Board meetings. This results in a cumulative history of each arrangement from one Board meeting to the next.

${ }^{9}$ We use data on tranching from 2003 onwards.
} 
Figure 3. Cumulative IMF Lending by Program Type: 1995-2019

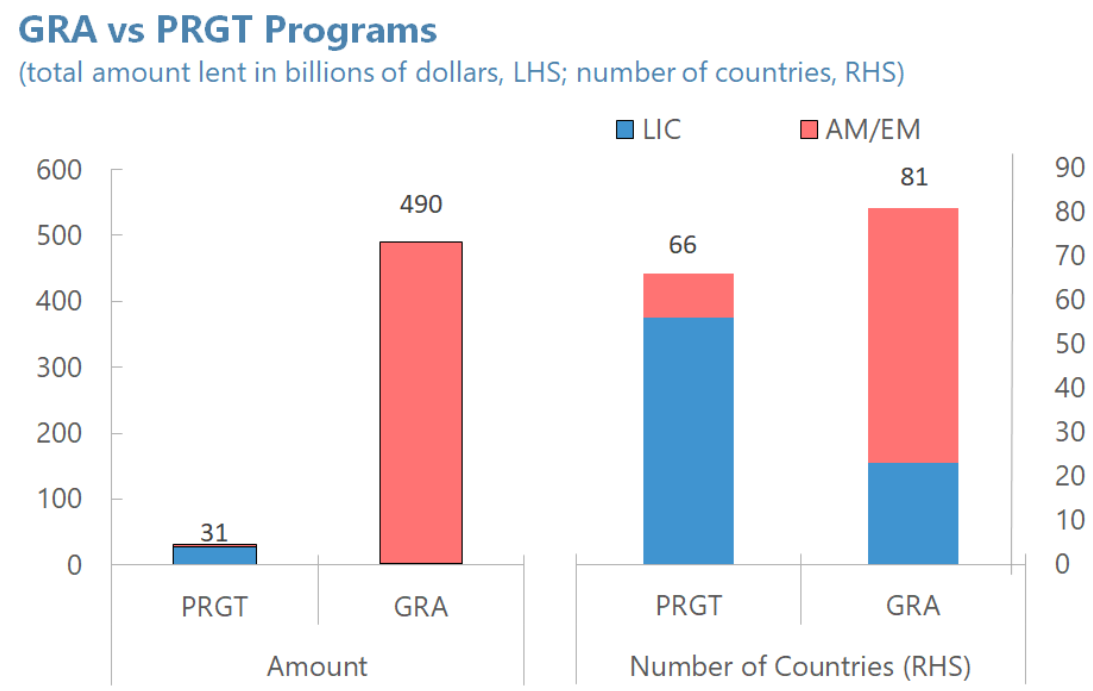

Standard vs Emergency Programs

(total amount lent in billions of dollars and number of countries)

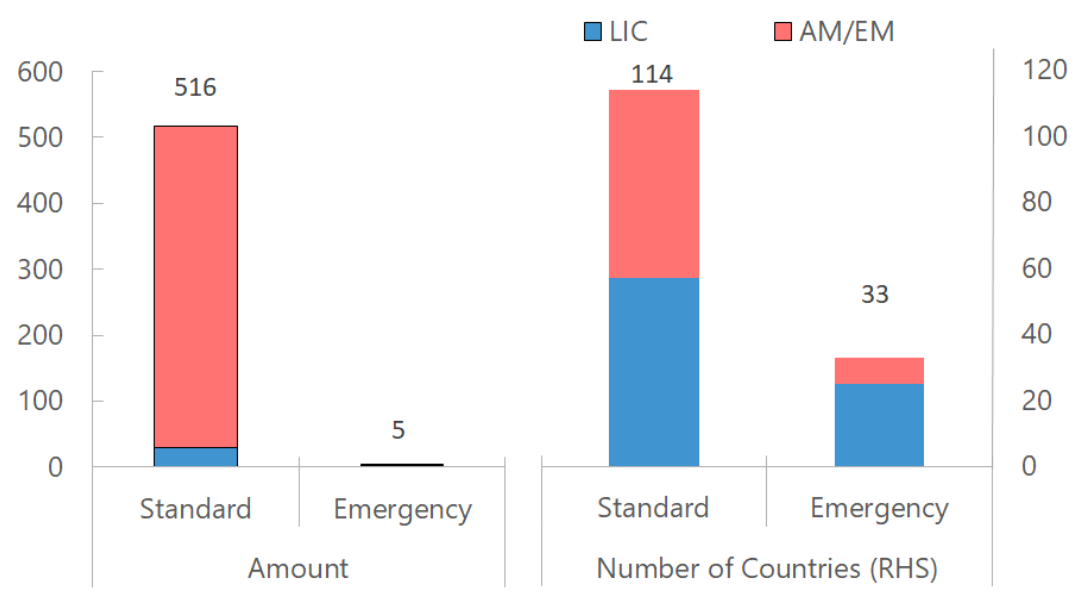

Note: These figures show the total amount lent by types of program across low income (LIC) and advanced or emerging economies (AM/EM). The figures summarize the time period between 1995-2019. The upper panel shows the split between GRA and PRGT programs and the lower panel between standard and emergency programs. The number of countries is a count of countries that have at least one arrangement of each program type.

Figure 3 shows that over the last two and half decades, the bulk of IMF lending has been under the GRA account, with the majority of recipient countries being advanced or emerging economies. The opposite is true for concessional lending under PRGT programs, which is concentrated amongst low income countries. Unsurprisingly, standard programs 
are far more common than emergency programs with little to no conditionality. Emergency programs tend to be concentrated among low-income countries, often in the wake of natural disasters or other calamities.

The analysis also employs data on other macroeconomic covariates such as GDP growth, oil export shares and corruption, which we obtain from the World Economic Outlook (WEO) and World Governance Indicators (WGI) databases. Table A1 reports summary statistics for the main variables used in our study.

\section{EMPIRICAL STRATEGY}

The primary objective of the analysis is to estimate the effect of IMF program disbursements on financial flows to OFCs. We restrict our sample to the 113 countries which have had at least one program arrangement with the IMF since the last quarter of 1995. Denoting $\mathrm{OFC}_{i t}$ as the aggregate (quarterly) deposits of country $i$ at time $t$ in all offshore destinations and $I M F_{i t}$ as a dummy indicating whether country $i$ received a disbursement at time $t$, we estimate the following equation by OLS:

$$
\Delta \log \left(\mathrm{OFC}_{i t}\right)=\beta \cdot I M F_{i t}+\Lambda \cdot \mathbf{X}_{\mathbf{i t}}+\alpha_{i}+\gamma_{t}+\varepsilon_{i t}
$$

The specification controls for country and time effects ( $\alpha_{i}$ and $\gamma_{t}$ respectively) and a vector of other macroeconomic covariates such as GDP growth $\left(\mathbf{X}_{\mathbf{i t}}\right)$. However, the specification is subject to obvious endogeneity concerns, for instance if the timing of disbursements coincides with unobservables related to economic stress that in turn affect crossborder flows. To address this issue, we employ first a specification using the differential growth rate of OFC to non-OFC flows as an outcome variable. This specification absorbs common unobservable shocks to cross-border flows which might emerge during times of economic stress. The modified equation we estimate is:

$$
\Delta \log \left(\mathrm{OFC}_{i t}\right)-\Delta \log \left(\mathrm{NOFC}_{i t}\right)=\beta \cdot I M F_{i t}+\Lambda \cdot \mathbf{X}_{\mathbf{i t}}+\alpha_{i}+\gamma_{t}+\varepsilon_{i t}
$$

The main identification assumption underlying Equation (2) is that flows to offshore and non-offshore destinations experience similar trends in the absence of IMF disbursements. This is akin to the common trends assumption in a difference-in-difference framework where the difference in the outcome (cross-border flows) remains similar between the treated (OFC destinations) and control (NOFC destinations) groups, in the absence of treatment (IMF disbursements). In principle, this requires that variables which are correlated with IMF disbursements, such as economic stress, do not alter the difference in flows to OFC and NOFC destinations. Later in section V we provide some empirical tests to validate this assumption. 
Another, arguably more flexible way to implement the above analysis is through a gravity specification, fully exploiting the granularity inherent in bilateral country flows. Let Deposit $_{i j t}$ denote the bilateral (quarterly) deposits of country $i$ in destination country $j$ at time $t$ and let $O_{j t}$ denote a dummy variable indicating whether or not the country $j$ is an offshore destination. Then:

$$
\Delta l o g\left(\text { Deposit }_{i j t}\right)=\beta \cdot I M F_{i t} \times O_{j t}+\omega_{i j}+\zeta_{i t}+\eta_{j t}+\varepsilon_{i j t}
$$

This specification allows us to control for country by destination fixed effects $\omega_{i j}$, country by time fixed effects $\zeta_{i t}$ (which absorbs the individual effect of $I M F_{i t}$ ) and destination by time fixed effects $\eta_{j t}$ (which absorbs the individual effect of $O_{j t}$ ). The country by destination fixed effects control for systematic deposit trends between a pair of countries (e.g., if country $i$ only sends deposits to a select few destinations). The remaining two types of fixed effects permit controlling for time-varying country and destination specific unobservables that could be jointly correlated with the timing of IMF disbursements and deposit flows (e.g., economic stress specific to country $i$ or financial integrity policy changes in destination $j$ ). It should be noted that the gravity specification, by virtue of its bilateral nature, increases the number of sample observations and enhances the power of the estimation, i.e. the probability of detecting a 'true' effect where it exists.

\section{Results}

\section{A. Baseline Specification}

Table 1 shows results from our baseline specification in Equation (1). Under the hypothesis that IMF loan disbursements are diverted to offshore destinations, we should expect a positive and statistically significant coefficient on the IMF disbursement dummy with respect to offshore flows. Column (A) shows this is not the case and IMF disbursement quarters are in fact associated with a lower growth rate to offshore destinations. Column (B) reports results from examining flows to non-offshore financial centers, and we find a positive but statistically insignificant effect of IMF disbursements on such flows. Column (C) reports findings from estimating the difference-in-difference specification (Equation

(2)) that differences out common cross-border shocks. The results indicate that there are no positive and statistically significant effects of IMF disbursements on the differential growth rate between offshore and non-offshore flows. The differential growth rate of flows are instead negatively associated with IMF disbursement quarters. 
Table 1. Effects of IMF Disbursement on Foreign Deposit Flows

\begin{tabular}{lccc}
\hline \hline & $\begin{array}{c}\text { Offshore Flows } \\
(\mathrm{A})\end{array}$ & $\begin{array}{c}\text { Non-Offshore Flows } \\
(\mathrm{B})\end{array}$ & $\begin{array}{c}\text { Diff. Flows } \\
(\mathrm{C})\end{array}$ \\
\hline & & & \\
IMF disbursement quarter & $-1.756^{* * *}$ & 0.937 & $-2.671^{* * *}$ \\
& $(0.637)$ & $(0.732)$ & $(0.861)$ \\
Quarterly GDP $(\mathrm{log})$ & 0.055 & -0.308 & 0.379 \\
& $(0.620)$ & $(0.610)$ & $(0.910)$ \\
\hline Observations & 10736 & 10704 & 10690 \\
Country F.E. & $\mathrm{X}$ & $\mathrm{X}$ & $\mathrm{X}$ \\
Time F.E. & $\mathrm{X}$ & $\mathrm{X}$ & $\mathrm{X}$ \\
\hline \hline
\end{tabular}

The table reports the average effects of IMF program on OFC and NOFC deposit flows. All columns report results from a panel fixed effects specification with country and time fixed effects. To account for possible dependence across results/observations for the same country, we cluster standard errors by country and reported these in parentheses. * indicates significance at $10 \% ;{ }^{* *}$ at $5 \% ;{ }^{* \star *}$ at $1 \%$.

To further ensure that Equation (2) is not contaminated by economic stress or other unobservable effects related to receiving IMF disbursements we restrict the estimation sample to only the duration of the IMF program. By focusing on country-time periods where an IMF program is in place, we exploit the timing of a new disbursement within quarters with plausibly similar levels of economic stress. Table 2 shows the results from this exercise, which are qualitatively very similar to those from our baseline specification. Column (A) shows that IMF disbursement quarters are associated with a lower growth rate to offshore destinations, while column (C) which differences out common cross-border shocks, shows that this holds even when considering the differential growth rate between offshore and non-offshore flows. In Annex Table A2 we also report results that are robust to adding pre-program quarterly dummies (upto four quarters before) to the restricted sample of country time periods where an IMF program was in place, enabling us to explicitly control for any pre-program trends or anticipation effects of the upcoming IMF program. 
Table 2. Effects of IMF Disbursement on Foreign Deposit Flows: Sample of IMF Program Period

\begin{tabular}{lccc}
\hline \hline & $\begin{array}{c}\text { Offshore Flows } \\
(\mathrm{A})\end{array}$ & $\begin{array}{c}\text { Non-Offshore Flows } \\
(\mathrm{B})\end{array}$ & $\begin{array}{c}\text { Diff. Flows } \\
(\mathrm{C})\end{array}$ \\
\hline \multirow{2}{*}{ IMF disbursement quarter } & $-2.440^{* *}$ & 0.193 & $-2.583^{* *}$ \\
& $(0.933)$ & $(0.955)$ & $(1.235)$ \\
Quarterly GDP (log) & 1.190 & 0.272 & 1.256 \\
& $(2.248)$ & $(1.364)$ & $(2.496)$ \\
\hline Observations & 3310 & 3282 & 3280 \\
Country F.E. & $\mathrm{X}$ & $\mathrm{X}$ & $\mathrm{X}$ \\
Time F.E. & $\mathrm{X}$ & $\mathrm{X}$ & $\mathrm{X}$ \\
\hline \hline
\end{tabular}

The table reports the average effects of IMF program on OFC and NOFC deposit flows. All columns report results from a panel fixed effects specification with country and time fixed effects. To account for possible dependence across results/observations for the same country, we cluster standard errors by country and reported these in parentheses. ${ }^{*}$ indicates significance at $10 \% ;{ }^{* *}$ at $5 \% ;{ }^{* * *}$ at $1 \%$.

In appendix tables A3 and A4 we report similar results using the publicly available BIS locational banking statistics data ${ }^{10}$. Both tables, one using the full sample and the other using the sample restricted to IMF program periods, show that our results are robust to using only publicly available data.

Next, we further investigate if there are anticipation effects or lags pertaining to IMF loan disbursements. If program disbursements are anticipated in the quarters leading up to the actual disbursement, then an increase in offshore flows might occur prior to the disbursement quarter. Conversely, it is possible that offshore flows occur with some lag after the funds have been received, in which case we would see the effect in the quarters following an actual disbursement. To explore these possibilities, we re-run the specification given by Equation (2) by adding lags and leads of up to four quarters. Figure 4 plots the results associated with the quarter of disbursement as well as its leads and lags; we find no evidence of any anticipated or lagged effects, with a negative and statistically significant effect holding only in the quarter of disbursement.

\footnotetext{
${ }^{10}$ These are available on the BIS data website.
} 
Figure 4. IMF disbursement effects: Lags and Future Horizons

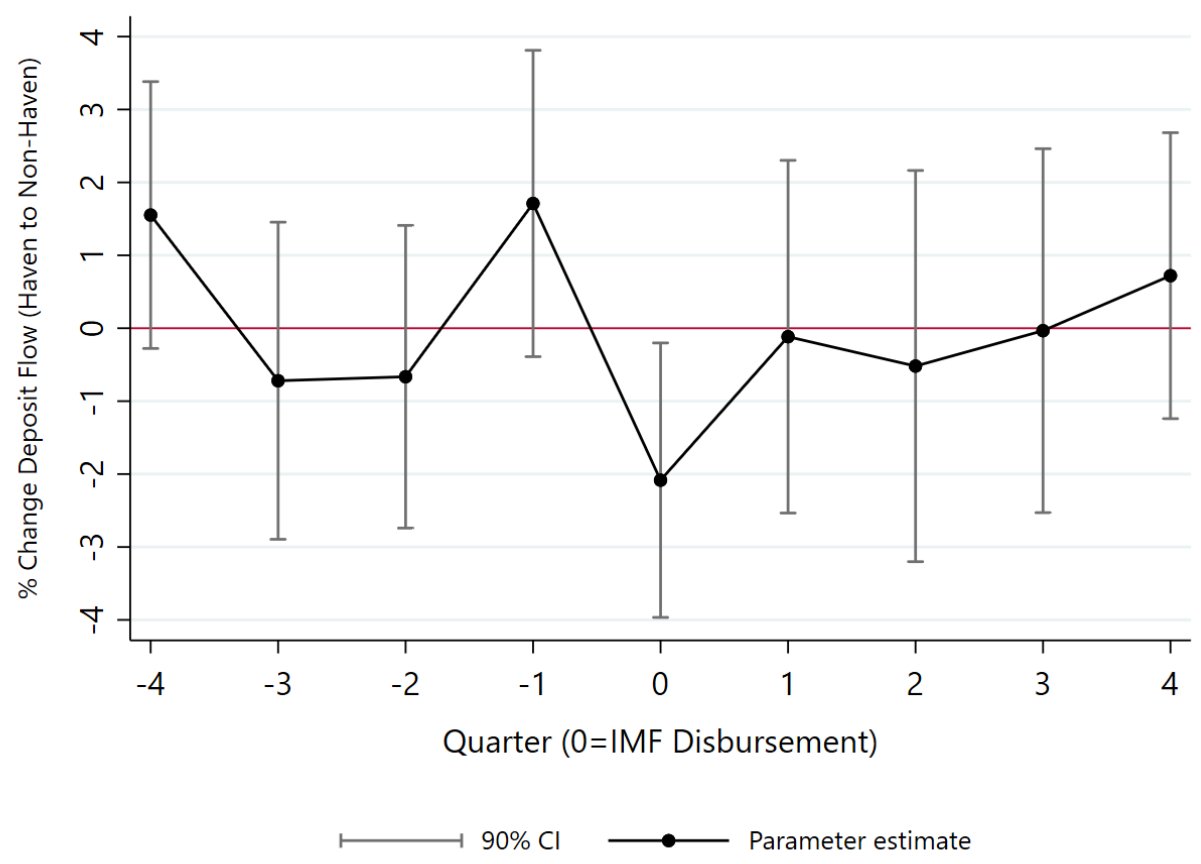

\section{B. Gravity Specification}

Table 3 shows results from the gravity specification of (Equation (3)). After controlling for country by time and destination by time fixed effects together with country-destination effects, we find that flows to offshore centers, as measured by the interaction term (IMF disbursement quarter $\times O F C$ ), are lower in IMF disbursement quarters (column (A)). This result holds after fully restricting the sample to IMF program and pre-program periods in column (B). Column (C) replaces the disbursement quarter dummy with a dummy variable indicating whether or not an IMF program is in place, and interacts it with the destination dummy. This specification allows us to examine whether there is an IMF program effect (as distinct from a disbrusement quarter effect), exploiting only the difference in destinations. There are no positive and statistically significant effects on offshore flows either in the quarter in which the funds are disbursed or over the entire duration of the IMF program. In the last column (D) we show that the baseline results hold even after restricting the sample to country time periods when an IMF program is in place, thus focusing attention on quarters with similar levels of economic stress while exploiting only the timing of loan disbursement. In this specification we find no statistically significant effects of IMF disbursements on (differential) offshore flows. 
Table 3. Gravity Model

\begin{tabular}{lcccc}
\hline \hline & $\begin{array}{c}\text { All Flows } \\
\text { (A) }\end{array}$ & $\begin{array}{c}\text { All Flows } \\
\text { (B) }\end{array}$ & $\begin{array}{c}\text { All Flows } \\
(\mathrm{C})\end{array}$ & $\begin{array}{c}\text { All Flows } \\
\text { (D) }\end{array}$ \\
\hline \multirow{3}{*}{ IMF disbursement quarter $\times$ Offshore } & $-1.161^{*}$ & $-1.691^{* *}$ & $-1.849^{*}$ & $-1.801^{*}$ \\
& $(0.686)$ & $(0.858)$ & $(0.992)$ & $(1.019)$ \\
IMF Program $\times$ Offshore & & & & \\
& & & 0.399 & \\
\hline Observations & 177226 & 60132 & 60132 & 45461 \\
Sample & $\mathrm{A}$ & $\mathrm{PP}$ & $\mathrm{PP}$ & $\mathrm{P}$ \\
Country by Destination F.E. & $\mathrm{X}$ & $\mathrm{X}$ & $\mathrm{X}$ & $\mathrm{X}$ \\
Country by Time F.E. & $\mathrm{X}$ & $\mathrm{X}$ & $\mathrm{X}$ & $\mathrm{X}$ \\
Destination by Time F.E. & $\mathrm{X}$ & $\mathrm{X}$ & $\mathrm{X}$ & $\mathrm{X}$ \\
\hline \hline
\end{tabular}

The table reports the average effects of IMF program and IMF disbursement on OFC and non-OFC deposit flows. All columns report results from a gravity model specification where the unit of analysis is the deposit flow between a source country and target destination. The specification includes high dimensional fixed effects with respect to country, destination and time. To account for possible dependence across results/observations for the same countrydestination pair, we cluster standard errors by country and destination and reported these in parentheses. A refers to all sample, PP refers to program and pre-program sample and $\mathrm{P}$ refers to program sample. ${ }^{*}$ indicates significance at $10 \%$; ${ }^{* *}$ at $5 \%$; ${ }^{* *}$ at $1 \%$.

\section{Explaining the Negative Effect}

Collectively, our baseline results suggest that IMF disbursements have a negative impact on flows to offshore destinations relative to other destinations. Note that any finding that rules out a significant positive impact suffices to answer the main question pursued by this study, viz. whether IMF disbursements are diverted to offshore centers. Moreover, as shown later in Section III.B, the negative impact becomes insignificant once we employ an instrumental variables approach to identification. Nonetheless, given the baseline results, it is worth thinking through why IMF aid disbursements might in fact differentially reduce outflows to OFCs relative to other destinations, contrary to the aid diversion hypothesis. Here we offer three possible explanations.

First, there may be a 'confidence effect' associated with IMF disbursements. The receipt of an IMF loan tranche associated with the successful completion of a review, might increase investor confidence in the economy. This could trigger either or both of (i) a decline in financial outflows by residents; and (ii) an increase in financial inflows by nonresidents. Erce and Riera-Crichton (2015) use data on gross capital flows to show that while IMF lending does not generally catalyze foreign capital, it does affect the behaviour of resident investors, who are both less likely to place their savings abroad and more likely to repatriate their foreign assets. Our results_-which suggest a reduction in resident outflows to offshore destinations in absolute and relative terms (relative to outflows to 
other destinations) — are consistent with this evidence. In particular, if local elites are more likely than others to maintain bank accounts in OFCs, and if these elites are more sensitive to the confidence channel than others, then that would provide an explanation for our results.

Second, recipients of IMF lending might be subject to a 'conditionality effect'. As noted previously, the disbursement of each loan tranche is conditional on a program review which monitors whether previously agreed macroeconomic targets-and often structural targets as well-have been met. The literature on foreign aid and corruption highlights this conditionality effect as a plausible channel for reducing corruption. For example, (Tavares, 2003) argues that aid linked to conditions works to limit the discretion available to recipient country officials. Later we investigate this channel further, by examining whether the negative impact on outflows is more pronounced for countries subject to greater conditionality. Our results indicate no clear pattern, suggesting that conditionality is not a dominant factor in driving the baseline effect; a more detailed discussion is reserved for Section VI.

Finally, IMF loan disbursements could ease certain budget constraints affecting the propensity to be corrupt, giving rise to a 'liquidity' effect. For instance, Knack (2001) discusses how foreign aid, insofar as it alleviates public revenue shortages and facilitates higher salaries for public employees, may diminish the propensity for corruption of public officials. Aid may also increase the resource base of reform-minded governments, and further better governance.

\section{Robustness of Baseline Results}

\section{A. Common Trends Assumption}

The assumption underlying our difference-in-difference specification is that deposit flows to offshore and non-offshore destinations have common trends in the absence of the IMF disbursement. To test this, and taking advantage of the extended time-period around IMF disbursements in our sample, we run a placebo specification. We construct our placebo sample by dropping all periods with an IMF program and artificially shifting the IMF disbursement quarter to either two or three quarters before the program is initiated. If there were indeed differential trends between offshore and non-offshore flows, then we would expect to see a statistically significant coefficient on the (artificial) IMF disbursement quarter dummy in the placebo sample.

Table 4 reports results, validating the common trends assumption. For reference, the first column shows the actual (non-placebo) effect corresponding to the result reported in Table 1 discussed previously. The coefficient on the disbursement quarter is negative and statistically significant, suggesting the presence of a differential effect on flows when an 
IMF loan tranche is received. In contrast, we find that in the placebo sample, the effect of the artificially constructed IMF disbursement dummy is statistically insignificant.

Table 4. Validating common trends assumption

\begin{tabular}{|c|c|c|c|}
\hline & \multicolumn{3}{|c|}{ Diff. Flows } \\
\hline & \multirow{2}{*}{$\begin{array}{c}\text { Actual disbursement } \\
\text { (baseline effect) } \\
(\mathrm{A})\end{array}$} & \multicolumn{2}{|c|}{ Placebo Disbursement } \\
\hline & & $\begin{array}{c}3 \text { quarters before } \\
\text { (B) }\end{array}$ & $\begin{array}{c}2 \text { quarters before } \\
\text { (C) }\end{array}$ \\
\hline IMF disbursement & $\begin{array}{c}-2.671^{* * *} \\
(0.860)\end{array}$ & & \\
\hline Placebo IMF disbursement & & $\begin{array}{l}-2.086 \\
(2.474)\end{array}$ & $\begin{array}{l}-2.083 \\
(2.674)\end{array}$ \\
\hline Observations & 10690 & 7149 & 7236 \\
\hline Country F.E. & $x$ & $x$ & $x$ \\
\hline Time F.E. & $x$ & $\mathrm{X}$ & $x$ \\
\hline
\end{tabular}

\section{B. Instrumental Variables Strategy using IMF Tranching}

As noted earlier, it is possible that the timing of IMF disbursements is correlated with contemporaneous shocks that affect cross-border flows independently. To mitigate bias from this source, we utilize an instrumental variable strategy, exploiting the scheduled timing of disbursements at the time of program arrangement.

To do so, we construct a binary variable $I M F_{i t}^{C}$, which takes the value of one if country $i$ was scheduled to receive a disbursement tranche at time $t$ at the time that the program was approved by the IMF's Executive Board, typically several quarters before the actual disbursement takes place. The variable $I M F_{i t}^{C}$ is used to predict the actual IMF disbursement dummy $I M F_{i t}$; we then estimate the structural equations (4) and (5) using two-stage least squares. It is important to note that the original schedule of disbursements will often differ from the actual pattern of disbursements for various reasons, including the noncompletion of a review. ${ }^{11}$

\footnotetext{
${ }^{11}$ As mentioned in the data section we use information on tranching from 2003 onwards; the results in this section therefore correspond to the 2003-2019 sample period. In our sample, about 40 percent of actual
} 


$$
I M F_{i t}=\zeta \cdot I M F_{i t}^{C}+\bar{\Lambda} \cdot \mathbf{X}_{\mathbf{i t}}+\bar{\alpha}_{i}+\bar{\gamma}_{t}+u_{i t}
$$

Let $\widehat{I M F}_{\text {it }}$ denote the predicted likelihood of a quarter having an IMF disbursement, obtained from Equation (4). Then:

$$
\Delta \log \left(\mathrm{OFC}_{i t}\right)-\Delta \log \left(\mathrm{NOFC}_{i t}\right)=\beta \cdot \widehat{I M F}_{i t}+\Lambda \cdot \mathbf{X}_{\mathbf{i t}}+\alpha_{i}+\gamma_{t}+\varepsilon_{i t}
$$

Our exclusion restriction is that scheduled disbursements $\left(I M F_{i t}^{C}\right)$ are uncorrelated with future shocks to offshore and non-offshore flows $\left(\hat{\varepsilon}_{i t}\right)$. Since the quarter in which the program is arranged is also typically the quarter of the first disbursement, we exclude from the sample the first quarter of every program. To further strengthen the exclusion restriction, we also exclude the second and third quarter of every IMF program; since it is possible-if unlikely-that "close by" future shocks could be perfectly anticipated when the program is arranged. This follows the methodology proposed by Kraay (2012) (see also Kraay, 2014).

Table 5 reports the results from this exercise. The large first stage F-statistic indicates that the instrument is strongly informative, with planned disbursements being highly correlated with actual disbursements. As shown by the columns of table 5 we remain unable to detect a positive and significant effect of the (instrumented) IMF disbursement quarter. Note, however, that the coefficient estimate in column $(\mathrm{C})$, the difference-indifference specification, is no longer statistically insignificant.

Table 5. Effects of IMF Disbursement on Foreign Deposit Flows: IV using planned disbursements

\begin{tabular}{lccc}
\hline \hline & $\begin{array}{c}\text { Offshore Flows } \\
(\mathrm{A})\end{array}$ & $\begin{array}{c}\text { Non-offshore Flows } \\
(\mathrm{B})\end{array}$ & $\begin{array}{c}\text { Diff. Flows } \\
(\mathrm{C})\end{array}$ \\
\hline & & & \\
IMF disbursement quarter & 3.984 & 4.917 & -1.914 \\
& $(4.034)$ & $(4.663)$ & $(6.068)$ \\
\hline Observations & 7046 & 7041 & 7041 \\
First-stage F & 408.6 & 408.3 & 408.3 \\
Country F.E. & $\mathrm{X}$ & $\mathrm{X}$ & $\mathrm{X}$ \\
Time F.E. & $\mathrm{X}$ & $\mathrm{X}$ & $\mathrm{X}$ \\
\hline \hline
\end{tabular}

The table reports the average effects of IMF program on offshore and non-offshore deposit flow for the sample period 2003-2019. Cluster-robust standard errors by country and reported these in parentheses. * indicates significance at $10 \%$; ${ }^{* *}$ at $5 \%$; ${ }^{* * *}$ at $1 \%$.

disbursement quarters differs from scheduled disbursement quarters (scheduled at the program approval stage). 


\section{Conditioning on Observable Sources of Economic Stress and Corruption}

In this section we check robustness to two separate factors that could influence our results: (i) time-varying shocks to corruption which could influence both the receipt of IMF disbursements and flows to offshore destinations and (ii) shocks to commodity prices that are often correlated with the onset of an IMF program and are known to have material effects on financial flows (see Andersen and others, 2017). Commodity shocks, in particular, are observable proxies for economic stress, and therefore demonstrate the robustness of our results to a shock that influences both the country's probability of receiving IMF funds and its pattern of financial flows. For corruption, we use the control of corruption index from the World Bank's World Governance Indicators (WGI). The index captures perceptions of the extent to which public power is exercised for private gain, including both petty and grand forms of corruption, as well as capture of the state by elites and private interests (see Kaufmann, Kraay, and Mastruzzi, 2011). The indicator is compiled from thirty different data sources which report the views of citizens, entrepreneurs, and experts in the public, private and NGO sectors, on the quality of various aspects of governance. While the index is annual, it should be noted that perceptions of corruption tend to be slow to move, so the variation over short time periods is limited.

Table 6 reports results after controlling for corruption. Column (A) shows that while it is the case that an increase in corruption is associated with higher differential flows to OFCs, this does not affect the sign of the base coefficient on IMF disbursement quarters. The IMF disbursement effect is negative and statistically significant in line with our baseline results. Next, in column (B) we also check if the effect of IMF disbursements is different in more corrupt countries. We are unable to find evidence in favor of this; the interaction effect (IMF Disbursement $\times$ Corruption) is negative and statistically insignificant. 
Table 6. Effects of IMF Disbursement on Foreign Deposit Flows: Controlling for Corruption

\begin{tabular}{lcc}
\hline \hline & \multicolumn{2}{c}{ Diff. Flows } \\
\cline { 2 - 3 } & $(\mathrm{A})$ & $(\mathrm{B})$ \\
\hline & 3.966 & $5.163^{* *}$ \\
Corruption Index & $(2.505)$ & $(2.527)$ \\
& & \\
IMF disbursement quarter & $-2.578^{* *}$ & -1.077 \\
& $(1.237)$ & $(1.910)$ \\
IMF Disbursement $\times$ Corruption & & -2.510 \\
\hline Observations & 3280 & 3280 \\
Country F.E. & $\mathrm{X}$ & $\mathrm{X}$ \\
Time F.E. & $\mathrm{X}$ & $\mathrm{X}$ \\
\hline \hline
\end{tabular}

The table reports the average effects of IMF program on offshore and non-offshore deposit flows with sample restricted to the IMF program duration. Cluster-robust standard errors by country and reported these in parentheses. ${ }^{*}$ indicates significance at $10 \%$; ${ }^{* *}$ at $5 \% ;{ }^{* * *}$ at $1 \%$.

Table 7 reports results after controlling for oil price shocks. In this specification we construct an oil shock variable which is the change in world oil prices (Brent) interacted with the extent of a country's oil share in exports. Note that the actual change in world oil prices is absorbed by the time fixed effects. Column (A) shows, in line with our baseline results, that IMF disbursement quarters are associated with a negative and statistically significant growth rate to offshore destinations, after explicitly controlling for the extent of oil shock experienced by a given country. Similarly in column (B) which differences out common cross-border shocks, we are unable to find a positive and statistically significant effect of IMF disbursement quarters even when conditioning additionally on the interaction between the oil shock and IMF disbursements. 
Table 7. Effects of IMF Disbursement on Foreign Deposit Flows: Controlling for Oil Shocks

\begin{tabular}{lcc}
\hline \hline & Diff. Flows & Diff. Flows \\
& $(\mathrm{A})$ & $(\mathrm{B})$ \\
\hline IMF disbursement quarter & $-2.356^{*}$ & $-2.338^{*}$ \\
& $(1.228)$ & $(1.226)$ \\
Oil Shock & & \\
& 0.179 & 0.271 \\
& $(0.255)$ & $(0.429)$ \\
Oil Shock $\times$ IMF disbursement & & -0.135 \\
& & $(0.411)$ \\
\hline Observations & 2492 & 2492 \\
Country F.E. & $\mathrm{X}$ & $\mathrm{X}$ \\
Time F.E. & $\mathrm{X}$ & $\mathrm{X}$ \\
\hline \hline
\end{tabular}

Sample restricted to country time periods with IMF programs. Cluster-robust standard errors by country and reported these in parentheses. ${ }^{*}$ indicates significance at $10 \%$; ${ }^{* *}$ at $5 \%$; ${ }^{* \star}$ at $1 \%$.

\section{HETERogeneity OF IMF DisbURSEMENT EFFECTS}

\section{A. By Program Concessionality and Conditionality}

In Table 8 we investigate whether the average effect masks heterogeneity with respect to the type of IMF program. First, we distinguish between the two main types of IMF loan arrangements: those made under the GRA (General Resources Account) versus those made under the PRGT (Poverty Reduction Growth Trust). As noted earlier, lending arrangements under the GRA comprise the bulk of IMF lending. These loans are provided at commercial rates, although the recipient country-which is facing economic stress by construction-would typically face higher rates in the market, or may be constrained from borrowing at any price. PRGT loans, on the other hand, provide concessional financing to low-income countries. ${ }^{12}$ Thus the main difference between the two types of program is that PRGT loans carry a higher degree of concessionality than GRA programs. We find that while GRA program disbursements are still negatively associated with differential outflows to OFCs, for PRGT disbursements the coefficient is smaller and insignificant (Column (A)).

\footnotetext{
${ }^{12}$ PRGT arrangements normally carry a zero interest rate and feature a grace period of several years before amortization commences. See https://www.imf.org/en/About/Factsheets/IMF-Lending and https://www.imf.org/en/About/Factsheets/IMF-Support-for-Low-Income-Countries for further details.
} 
Table 8. Effects of IMF Disbursement on Foreign Deposit Flows: by Program (IMF Program Sample)

\begin{tabular}{lcc}
\hline \hline & \multicolumn{2}{c}{ Diff. Flows } \\
\cline { 2 - 3 } & $\begin{array}{c}\text { Program Type } \\
(\mathrm{A})\end{array}$ & $\begin{array}{c}\text { Conditionality Type } \\
\text { (B) }\end{array}$ \\
\hline PRGT Disbursement Quarter & $-2.414^{*}$ & \\
& $(1.453)$ & \\
GRA Disbursement Quarter & -3.024 & \\
& $(2.208)$ & 1.539 \\
Quarterly GDP (log) & 1.276 & $(2.488)$ \\
& $(2.493)$ & 6.210 \\
Emergency Relief Disbursement Quarter & & $(5.762)$ \\
& & $-2.841^{* *}$ \\
Standard Program Disbursement Quarter & & $(1.204)$ \\
& & 3280 \\
Observations & 3280 & $X$ \\
Country & $X$ & $X$ \\
Time F.E. & $X$ & \\
\hline \hline
\end{tabular}

The table reports the average effects of IMF program on OFC and non-OFC deposit flows. All columns report results from a panel fixed effects specification with country and time fixed effects. To account for possible dependence across results/observations for the same country, we cluster standard errors by country and reported these in parentheses. ${ }^{*}$ indicates significance at $10 \%$; ${ }^{* *}$ at $5 \%$; ${ }^{* *}$ at $1 \%$.

In Column (B) of table 8 we explore a different split, based on the degree of conditionality of the program. We distinguish between programs that have standard conditionality associated with each program review and those that are disbursed as emergency relief, carrying little to no conditionality. The latter include IMF assistance under the Rapid Credit Facility (RCF) and Rapid Financing Assistance (RFI) programs that aim to provide immediate and concessional financial assistance to mainly low-income countries ${ }^{13}$ facing an urgent balance of payments need. These loans are disbursed without explicit program-based conditionality or program reviews. Column (B) reports results from this split. We find that standard program disbursements are associated with lower differential outflows to OFCs. While the effect for emergency relief disbursements is positive, it is not statistically significant. This last result should be interpreted cautiously, however, given the low amount of variation in emergency relief programs relative to standard program within our sample.

\footnotetext{
${ }^{13}$ While the RFI is available for all IMF member countries, its take-up has been concentrated amongst low-income countries.
} 


\section{B. By Program Amounts}

Table 9 examines whether the effect of IMF disbursements on offshore flows is non-linear depending on the amount disbursed. We re-run our baseline specification, split into three mutually exclusive country groups, based on the average quarterly disbursements received over the entire period. In column (A) we report results from the sample of countries in which the loan disbursement, on average, was less than 1.5 percent of quarterly GDP; the results for this sample are similar to our baseline results. In Column (B) we focus on disbursement amounts between 1.5 and 2.5 percent of quarterly GDP, and find that again the effect of IMF disbursements on differential OFC flows is negative but not statistically significant. In Column (C) we examine program disbursements which exceed 2.5 percent of quarterly GDP; the results show that while there is a positive effect, with IMF disbursements associated with an increase in deposit growth to offshore centers (relative to deposit growth in non-offshore centers), the effect is statistically insignificant.

Table 9. Effects of IMF Disbursement on Foreign Deposit Flows: Threshold Effects of Disbursement Amount

\begin{tabular}{lccc}
\hline \hline & \multicolumn{3}{c}{ Average IMF funds received (quarterly) } \\
\cline { 2 - 4 } & $<1.5 \%$ Q-GDP & $1.5-2.5 \%$ Q-GDP & $>2.5 \%$ Q-GDP \\
& $(\mathrm{A})$ & $(\mathrm{B})$ & $(\mathrm{C})$ \\
\hline \multirow{3}{*}{ IMF disbursement quarter } & -2.381 & -3.561 & 0.736 \\
& $(1.889)$ & $(2.484)$ & $(2.730)$ \\
\hline Observations & 1430 & 1048 & 802 \\
Country F.E. & $\mathrm{X}$ & $\mathrm{X}$ & $\mathrm{X}$ \\
Time F.E. & $\mathrm{X}$ & $\mathrm{X}$ & $\mathrm{X}$ \\
\hline \hline
\end{tabular}

The table reports the average effects of IMF program on offshore and non-offshore deposit flows with the sample restricted to the IMF program duration. Cluster-robust standard errors by country and reported these in parentheses. * indicates significance at $10 \% ;{ }^{* *}$ at $5 \%$; ${ }^{* * *}$ at $1 \%$.

\section{Additional Evidence from the Covid-19 Sample Period}

In this section, we extend our sample to the time-period covering the Covid-19 crisis. In Table 10 we restrict the sample to the second and third quarter of 2020, when IMF emergency lending peaked in response to the Covid-19 pandemic (see Figure 1). Note that this specification provides a quasi-natural setting, allowing us to test whether aid in response to exogenous shocks is diverted. The results indicate that this is not the case. Column (A) and Column (B) show that IMF disbursements are associated with a statistically insignificant increase in flows to both offshore and non-offshore destinations during the 
surge in pandemic related IMF lending. Moreover, in Column (C) we also find a statistically insignificant effect (with a large confidence interval) of IMF disbursements on the differential growth rate between offshore and non-offshore flows.

Table 10. IMF Disbursement Foreign Deposit Flows: Covid-19 Effect

\begin{tabular}{lccc}
\hline \hline & $\begin{array}{c}\text { Offshore Flows } \\
(\mathrm{A})\end{array}$ & $\begin{array}{c}\text { Non-Offshore Flows } \\
(\mathrm{B})\end{array}$ & $\begin{array}{c}\text { Diff. Flows } \\
(\mathrm{C})\end{array}$ \\
\hline & & & \\
IMF disbursement quarter & 6.801 & 5.097 & 1.704 \\
& $(5.680)$ & $(3.434)$ & $(6.644)$ \\
\hline Observations & 244 & 244 & 244 \\
Country F.E. & $\mathrm{X}$ & $\mathrm{X}$ & $\mathrm{X}$ \\
Time F.E. & $\mathrm{X}$ & $\mathrm{X}$ & $\mathrm{X}$ \\
\hline \hline
\end{tabular}

The table reports the average effects of IMF program on OFC and non-OFC deposit flows over the 2020 Q2-Q3 time period. All columns report results from a panel fixed effects specification with country and time fixed effects. To account for possible dependence across results/observations for the same country, we cluster standard errors by country and reported these in parentheses. * indicates significance at $10 \%$; ${ }^{* *}$ at $5 \%$; ${ }^{* * *}$ at $1 \%$.

\section{Conclusion}

While there is a considerable literature on the structural relationship between foreign aid and corruption, the question of whether foreign aid is diverted to offshore OFCs-thus precluding it from being used for its intended purpose-is much less examined. In this paper we have investigated whether IMF lending is subject to such aid diversion, drawing from data covering the last quarter century. In sharp contrast to the findings of Andersen, Johannesen, and Rijkers (2020) for World Bank aid, we find no evidence that IMF disbursements are associated with increased outflows to offshore financial centers. This is true both in absolute terms, and more importantly, relative to outflows to other destinations. The finding is robust to several different specifications and identification strategies.

Of course, the appropriation of multilateral assistance could occur in other ways than the diversion of funds to offshore bank accounts. Most obviously, stolen money could be held domestically. Our results therefore do not demonstrate that IMF assistance is never appropriated by local elites. But we do show that one important channel through which this might be expected to happen-and does happen with respect to other multilateral aid flows - seems inoperative. And while our results indicate a positive association between corruption - as measured by the WGI control of corruption index-and outflows to offshore bank accounts; IMF disbursements do not appear to amplify this link. 
Our work also suggests strongly that whether or not foreign aid is captured and diverted by local elites depends on the type and source of the aid. Fleshing out this finding would comprise a research agenda with important practical applications. We make some initial progress on this issue, mainly by suggesting that program conditionality - an integral aspect of IMF lending - is not the dominant reason for its apparent resistance to elite capture. But more work is needed to understand precisely what design features of foreign aid are responsible for how easy or difficult it is to divert. More broadly, the issue of aid diversion could also be examined with respect to bilateral aid flows, which may differ from multilateral aid flows in magnitude, scope and purpose. 


\section{REFERENCES}

Alesina, Alberto, and Beatrice Weder, 2002, "Do corrupt governments receive less foreign aid?” American Economic Review, Vol. 92, No. 4, pp. 1126-1137.

Alstadsæter, Annette, Niels Johannesen, and Gabriel Zucman, 2019, "Tax evasion and inequality," American Economic Review, Vol. 109, No. 6, pp. 2073-2103.

Andersen, Jørgen Juel, Niels Johannesen, David Dreyer Lassen, and Elena Paltseva, 2017, "Petro rents, political institutions, and hidden wealth: Evidence from offshore bank accounts," Journal of the European Economic Association.

Andersen, Jørgen Juel, Niels Johannesen, and Bob Rijkers, 2020, "Elite Capture of Foreign Aid: Evidence from Offshore Bank Accounts," World Bank Policy Research Working Paper 9150.

BIS, 2020, "Global coverage of BIS locational banking statistics," Bank for International Settlements.

Dreher, Axel, 2006, "IMF and economic growth: The effects of programs, loans, and compliance with conditionality," World Development, Vol. 34, No. 5, pp. 769-788.

_ 2009, "IMF conditionality: theory and evidence," Public choice, Vol. 141, No. 1-2, pp. 233-267.

Dykstra, Sarah, Amanda Glassman, Charles Kenny, and Justin Sandefur, 2019, "Regression discontinuity analysis of Gavi's impact on vaccination rates," Journal of Development Economics, Vol. 140, pp. 12-25.

IMF, 2000, "Offshore financial centers: IMF background paper," .

__ 2018, “2018 Review of Program Design and Conditionality,” .

_ 2019, "A strategy for IMF engagement on social spending - Background Paper II," .

Johannesen, Niels, and Gabriel Zucman, 2014, "The end of bank secrecy? An evaluation of the G20 tax haven crackdown," American Economic Journal: Economic Policy, Vol. 6, No. 1, pp. 65-91.

Kaufmann, Daniel, Aart Kraay, and Massimo Mastruzzi, 2011, "The Worldwide Governance Indicators: Methodology and Analytical Issues1," Hague journal on the rule of law, Vol. 3, No. 2, pp. 220-246.

Knack, Stephen, 2001, "Aid dependence and the quality of governance: cross-country empirical tests," Southern economic journal, pp. 310-329.

Kraay, Aart, 2012, "How large is the government spending multiplier? Evidence from World Bank lending," The Quarterly Journal of Economics, Vol. 127, No. 2, pp. 829887. 
_ 2014, "Government spending multipliers in developing countries: evidence from lending by official creditors," American Economic Journal: Macroeconomics, Vol. 6, No. 4, pp. 170-208.

Londoño-Vélez, Juliana, and Javier Ávila-Mahecha, 2018, "Can wealth taxation work in developing countries? Quasi-experimental evidence from Colombia," in Annual Congress of the IIPF.

Menard, Audrey-Rose, and Laurent Weill, 2016, "Understanding the link between aid and corruption: A causality analysis," Economic Systems, Vol. 40, No. 2, pp. 260-272.

Okada, Keisuke, and Sovannroeun Samreth, 2012, "The effect of foreign aid on corruption: A quantile regression approach,” Economics Letters, Vol. 115, No. 2, pp. 240243.

Quibria, MG, 2014, "Aid effectiveness: research, policy and unresolved issues," Development Studies Research. An Open Access Journal, Vol. 1, No. 1, pp. 75-87.

Steinwand, Martin C, and Randall W Stone, 2008, “The International Monetary Fund: A review of the recent evidence," The Review of International Organizations, Vol. 3, No. 2, pp. 123-149.

Svensson, Jakob, 2000, "When is foreign aid policy credible? Aid dependence and conditionality," Journal of development economics, Vol. 61, No. 1, pp. 61-84.

Tavares, Jose, 2003, “Does foreign aid corrupt?” Economics Letters, Vol. 79, No. 1, pp. 99-106.

Zucman, Gabriel, 2013, "The missing wealth of nations: Are Europe and the US net debtors or net creditors?" The Quarterly journal of economics, Vol. 128, No. 3, pp. 1321-1364. 


\section{Appendices}

Figure A1. Example of IMF program disbursement - Phasing \& Schedule

\begin{tabular}{|c|c|c|c|c|}
\hline Date of availability & Condition for disbursement & $\begin{array}{c}\text { Amount } \\
\text { (millions of SDRs) }\end{array}$ & $\begin{array}{c}\text { Amount } \\
\text { (millions of US\$) }\end{array}$ & $\begin{array}{c}\text { Percentage of } \\
\text { Quota 1/ }\end{array}$ \\
\hline June 19, 2017 & $\begin{array}{l}\text { Approval of the extended arrangement } \\
\text { under the EFF. }\end{array}$ & 71.430 & 96.649 & 33.069 \\
\hline December 1, 2017 & $\begin{array}{l}\text { Observance of PCs for end-June 2017, } \\
\text { continuous PCs and completion of the first } \\
\text { review. }\end{array}$ & 71.430 & 96.649 & 33.069 \\
\hline June 1, 2018 & $\begin{array}{l}\text { Observance of PCs for end-December 2017, } \\
\text { continuous PCs and completion of second } \\
\text { review. }\end{array}$ & 71.430 & 96.649 & 33.069 \\
\hline December 1, 2018 & $\begin{array}{l}\text { Observance of PCs for end-June 2018, } \\
\text { continuous PCs and completion of third } \\
\text { review. }\end{array}$ & 71.430 & 96.649 & 33.069 \\
\hline June 1, 2019 & $\begin{array}{l}\text { Observance of PCs for end-December 2018, } \\
\text { continuous PCs and completion of fourth } \\
\text { review. }\end{array}$ & 71.430 & 96.649 & 33.069 \\
\hline December 1, 2019 & $\begin{array}{l}\text { Observance of PCs for end-June 2019, } \\
\text { continuous PCs and completion of fifth } \\
\text { review. }\end{array}$ & 71.430 & 96.649 & 33.069 \\
\hline \multirow[t]{2}{*}{ April 30, 2020} & $\begin{array}{l}\text { Observance of PCs for end-December 2019, } \\
\text { continuous PCs and completion of sixth } \\
\text { review. }\end{array}$ & 35.820 & 48.467 & 16.583 \\
\hline & Total & 464.400 & 628.362 & 215.000 \\
\hline
\end{tabular}

Source: IMF staff projections.

$1 /$ Gabon's quota is SDR 216.0 million.

The source for this figure is IMF country report No. 17/205 (Gabon - Request for an Extended Arrangement Under the Extended Fund Facility, 2017). PC reference to performance criteria or conditionalities associated with review completion. 
Table A1. Descriptive Statistics

\begin{tabular}{|c|c|c|c|}
\hline & Observations & Mean & Standard Deviation \\
\hline Offshore Deposit Flow ${ }^{1}$ & 10690 & 1.229 & 23.800 \\
\hline Non-Offshore Deposit Flow ${ }^{2}$ & 10690 & 1.750 & 28.603 \\
\hline IMF Program $^{\dagger}$ & 10690 & 0.307 & 0.461 \\
\hline IMF Disbursement (Quarterly) ${ }^{\dagger}$ & 10690 & 0.153 & 0.360 \\
\hline PRGT Disbursement (Quarterly) ${ }^{\dagger}$ & 10690 & 0.096 & 0.295 \\
\hline GRA Disbursement (Quarterly) ${ }^{\dagger}$ & 10690 & 0.057 & 0.232 \\
\hline Emergency Relief Disbursement (Quarterly) ${ }^{\dagger}$ & 10690 & 0.008 & 0.087 \\
\hline Standard Program Disbursement (Quarterly) ${ }^{\dagger}$ & 10690 & 0.146 & 0.353 \\
\hline Corruption Index ${ }^{3}$ & 10674 & 0.437 & 0.708 \\
\hline $\begin{array}{l}\text { Average Quarterly Disbursement } \\
\text { (percent of quarterly GDP) }\end{array}$ & 3280 & 2.201 & 2.034 \\
\hline
\end{tabular}

The table reports summary statistics for the main variables used in our analysis. ${ }^{\dagger}$ are dummy variable. ${ }^{1}$ is the quarterly percentage change in deposits held in countries classified as offshore (measured as the change in quarterly log-levels). ${ }^{2}$ is the quarterly percentage change in deposits held in countries not classified as offshore (measured as the change in quarterly log-levels). ${ }^{3}$ measured as the negative of the corruption index from the World Bank's World Governance Indicators. ${ }^{4}$ Average quarterly disbursement based on the sample of IMF programs (excluding non-program periods).

Table A2. Effects of IMF Disbursement on Foreign Deposit Flows: Sample of IMF Program \& Pre-Program Period

\begin{tabular}{lccc}
\hline \hline & $\begin{array}{c}\text { Offshore Flows } \\
(\mathrm{A})\end{array}$ & $\begin{array}{c}\text { Non-Offshore Flows } \\
(\mathrm{B})\end{array}$ & $\begin{array}{c}\text { Diff. Flows } \\
(\mathrm{C})\end{array}$ \\
\hline \multirow{3}{*}{ IMF disbursement quarter } & $-2.363^{* *}$ & 0.306 & $-2.613^{* *}$ \\
& $(0.903)$ & $(0.927)$ & $(1.178)$ \\
& & & \\
Quarterly GDP $(\mathrm{log})$ & -1.200 & -0.579 & -0.374 \\
& $(1.454)$ & $(1.026)$ & $(1.883)$ \\
\hline Observations & 4184 & 4148 & 4146 \\
Country F.E. & $\mathrm{X}$ & $\mathrm{X}$ & $\mathrm{X}$ \\
Time F.E. & $\mathrm{X}$ & $\mathrm{X}$ & $\mathrm{X}$ \\
\hline \hline
\end{tabular}

The table reports the average effects of IMF program on OFC and non-OFC deposit flows. All columns report results from a panel fixed effects specification with country and time fixed effects as well as additional pre-program quarterly dummies (upto 4 quarters before). To account for possible dependence across results/observations for the same country, we cluster standard errors by country and reported these in parentheses. ${ }^{*}$ indicates significance at $10 \% ;{ }^{* *}$ at $5 \% ;{ }^{* * *}$ at $1 \%$. 
Table A3. Effects of IMF Disbursement on Foreign Deposit Flows - Public Database

\begin{tabular}{lccc}
\hline \hline & $\begin{array}{c}\text { Offshore Flows } \\
(\mathrm{A})\end{array}$ & $\begin{array}{c}\text { Non-Offshore Flows } \\
(\mathrm{B})\end{array}$ & $\begin{array}{c}\text { Diff. Flows } \\
(\mathrm{C})\end{array}$ \\
\hline & & & \\
IMF disbursement quarter & $-1.666^{* *}$ & $1.588^{* *}$ & $-3.207^{* * *}$ \\
& $(0.661)$ & $(0.795)$ & $(0.935)$ \\
Quarterly GDP $(\mathrm{log})$ & 0.433 & 0.257 & 0.508 \\
& $(0.706)$ & $(0.834)$ & $(1.098)$ \\
\hline Observations & 10622 & 10533 & 10501 \\
Country F.E. & $\mathrm{X}$ & $\mathrm{X}$ & $\mathrm{X}$ \\
Time F.E. & $\mathrm{X}$ & $\mathrm{X}$ & $\mathrm{X}$ \\
\hline \hline
\end{tabular}

The table reports the average effects of IMF program on OFC and NOFC deposit flows. All columns report results from a panel fixed effects specification with country and time fixed effects. To account for possible dependence across results/observations for the same country, we cluster standard errors by country and reported these in parentheses. ${ }^{*}$ indicates significance at $10 \%$; ${ }^{* *}$ at $5 \%$; ${ }^{* * *}$ at $1 \%$.

Table A4. Effects of IMF Disbursement on Foreign Deposit Flows: Sample of IMF Program Period - Public Database

\begin{tabular}{lccc}
\hline \hline & $\begin{array}{c}\text { Offshore Flows } \\
(\mathrm{A})\end{array}$ & $\begin{array}{c}\text { Non-Offshore Flows } \\
(\mathrm{B})\end{array}$ & $\begin{array}{c}\text { Diff. Flows } \\
(\mathrm{C})\end{array}$ \\
\hline \multirow{3}{*}{ IMF disbursement quarter } & $-2.125^{* *}$ & 1.561 & $-3.695^{* *}$ \\
& $(0.954)$ & $(1.157)$ & $(1.411)$ \\
& & & \\
Quarterly GDP $(\mathrm{log})$ & 1.167 & 0.835 & 1.229 \\
& $(2.099)$ & $(1.793)$ & $(2.724)$ \\
\hline Observations & 3306 & 3248 & 3243 \\
Country F.E. & $\mathrm{X}$ & $\mathrm{X}$ & $\mathrm{X}$ \\
Time F.E. & $\mathrm{X}$ & $\mathrm{X}$ & $\mathrm{X}$ \\
\hline \hline
\end{tabular}

The table reports the average effects of IMF program on OFC and NOFC deposit flows. All columns report results from a panel fixed effects specification with country and time fixed effects. To account for possible dependence across results/observations for the same country, we cluster standard errors by country and reported these in parentheses. ${ }^{*}$ indicates significance at $10 \% ;{ }^{* *}$ at $5 \% ;{ }^{* *}$ at $1 \%$. 